\title{
Effects of macroepifauna on developing nematode and harpacticoid assemblages in a subtidal muddy habitat
}

\author{
Emil Ólafsson*, Colin G. Moore \\ Department of Biological Sciences, Heriot-Watt University, Riccarton, Edinburgh EH14 4AS, Scotland, UK
}

\begin{abstract}
In order to assess the effects of macrofauna on meiofaunal community structure, field investigations were performed in a low energy subtidal muddy sediment in Loch Creran, a sea-loch on the west coast of Scotland. Meiofaunal colonization of azoic sediment was studied in cages designed to exclude macrofauna to varying degrees. In all the cages high diversity assemblages developed rapidly. Considerable variation in species composition was found, both for nematodes and harpacticoids, and no indication that exclusion of the macrofauna was influencing the early colonizing individuals. For the harpacticoid species the results from multivariate analyses indicated a strong successional pattern inside the cages. However such a pattern was not obvious for the nematode component of the meiofauna. The semi-pelagic harpacticoid copepod Longipedia helgolandica became extremely abundant inside the cages, while it was hardly found in the background sediment. The initial colonization by most of the harpacticoids was marked by a high proportion of copepodites. The exclusion of macroepifauna did not result in a simpler meiofaunal community as one would expect if suppression of dominant competitive relationships by macroepifauna occurred. This study emphasizes the complexity of the community organization, where multitrophic relationships may be of vital importance as factors influencing community structure.
\end{abstract}

\section{INTRODUCTION}

Experimental work on macrofaunal communities has demonstrated the importance of biological factors as major organizing forces controlling community structure. Many studies on marine rocky intertidal macrofauna have shown that disturbance (biological and physical) can suppress dominant competitive relationships and lead to higher diversity communities (Paine 1966, Connell 1970, Dayton 1971; see review by Menge \& Sutherland 1976).

In unvegetated soft bottom habitats, epibenthic predator exclusion experiments have often resulted in higher density and enhanced species richness inside exclusion cages (Naqvi 1968, Reise 1977, Virnstein 1977. Wiltse 1977, Holland et al. 1980) which is in direct contrast with the competitive exclusion model sug-

\footnotetext{
- Present address: Department of Zoology, Stockholm Uni-
} versity, S-106 91 Stockholm, Sweden gested for rocky intertidal communities (Peterson 1979).

Re-examination of data from exclusion experiments in soft sediments has shown that predatory infauna became proportionally more abundant following exclusion of epibenthic predators (Ambrose 1984a). Some predatory infauna have been shown to reduce infaunal densities (Reise 1979, Wiltse 1980, Commito 1982, Ambrose 1984b, c) hence Ambrose (1984a) suggested that lack of competitive exclusion where epibenthic predators have been removed might be due to increasing predation pressure by the macroinfauna. He proposed a 3-level interactive model composed of epibenthic predators, predatory infauna and other infauna. There is increasing evidence that the predatory infauna structures soft bottom communities (Kent \& Day 1983, Commito \& Ambrose 1985a, b, Commito \& Shrader 1985, Ambrose 1986, Schubert \& Reise 1986), and these studies emphasize the complexities of community organization in soft bottoms rather than providing clear cut principles. 
Meiofauna may share ecological properties with the macrofauna despite physical or biological factors operating on much smaller spatial and temporal scales. Recently the non-equilibrium diversity theories of Connell (1978) and Huston (1979) have been used to explain variations in species diversity in meiofaunal assemblages (Platt \& Lambshead 1985, Warwick et al. 1986). The hypothesis predicts that under low frequency and intensity of disturbance diversity is low due to competitive exclusion, while intermediate disturbance yields high diversity by preventing competition leading to exclusion of species. Further increase of the scale of disturbance results in lower diversity as species may be eliminated by the force of the disturbance.

Biological disturbance which can include selective and non-selective predation as well as a variety of habitat modifications may influence the structure of meiofaunal assemblages (Reise \& Ax 1979, Thistle 1980, Reidenauer \& Thistle 1981, Sherman et al. 1983, Creed \& Coull 1984, Hicks 1984, Warwick et al. 1986, Palmer 1988, Warwick et al. 1990, Ólafsson et al. 1990, Ólafsson \& Elmgren 1991).

In an earlier contribution (Ólafsson \& Moore 1990) we reported on an exclusion experiment with the aim of assessing the extent to which meiofaunal communities are structured by macrofauna in subtidal muddy sediments. There we concentrated on changes in density of recolonizing meiofauna due to exclusion of macroepifauna. Here we describe changes in other community parameters e.g. species diversity, abundance and succession.

\section{MATERIALS AND METHODS}

Experimental procedure. Predator exclusion cages and several types of controls were established on the seabed in Loch Creran, a sea-loch on the west coast of Scotland. The study area, the basic cage design and the establishment of the cages on the seabed is described by Ólafsson (1989) and Ólafsson \& Moore (1990). Azoic frozen mud blocks were placed inside each cage at the beginning of the experiment. Six treatments, each of 3 replicates, were employed. The codes and details of the treatments are as follows:

1 ( $1 \mathrm{~mm}$ cages): These cages were covered in $1 \mathrm{~mm}$ aperture mesh, being designed to exclude all macrofauna.

1C (1 mm control cages): These were identical to the $1 \mathrm{~mm}$ cages, except that the 2 narrower ends of the cage framework were left open. This allowed entry of macrofauna, while producing similar current and sedimentary regimes within the cages. The meshed sides of the cage were placed normal to the prevailing current direction.
10 (10 mm cages): These cages were covered in $10 \mathrm{~mm}$ aperture mesh, being designed to exclude only the larger macrofauna.

$10 \mathrm{C}(10 \mathrm{~mm}$ control cages): Identical to the $10 \mathrm{~mm}$ cages apart from the 2 ends of the cages remaining unmeshed.

OC (Open control cages): These consisted of the basic cage framework, all sides and the top remaining unmeshed. These permitted examination of biotic changes resulting from unwanted modification of the physical and chemical conditions within the other cage types.

$B C$ (Background controls): Areas of seabed, each of approximately the same surface area as an exclusion cage, were delimited with wooden pegs.

The cages $(43 \times 35 \times 25 \mathrm{~cm})$ were placed in random order at $2 \mathrm{~m}$ intervals along 2 arrays $2 \mathrm{~m}$ apart. Azoic frozen mud blocks were placed inside each cage (flush wilh the surrounding sediment), but not the background area, at the beginning of the experiment.

Meiofaunal samples and salinity and temperature measurements were taken monthly from July to September 1986 and in February 1987. Samples from the second month were not analyzed, to cut down extensive processing time. From each replicate cage three $5 \mathrm{~cm}$ deep cores, each of $11.34 \mathrm{~cm}^{2}$ crosssectional area, were retrieved with hand-held perspex tubes and preserved in $4 \%$ seawater formalin. The meiofauna was extracted from the sediment by centrifugation in Ludox TM colloidal silica (Platt \& Warwick 1983) using a $45 \mu \mathrm{m}$ sieve

After extraction and enumeration of the major taxa from the 3 replicates from each cage, the samples were lumped together and mixed thoroughly. The samples were then dispersed in a gridded Petri dish and all the nematodes in randomly chosen squares transferred to a solid watchglass containing a 1:1:18, by volume, mixture of glycerol, ethanol and water (Seinhorst 1959, Platt \& Warwick 1983). At least 200 individuals of nematodes were picked out of each lumped sample and a further 200 individual harpacticoids (numbers permitting). The identity, sex and stage (adult or juvenile) of each individual was noted using a high power compound microscope

Data handling. In order to assess major trends, the data sets were subjected to both classification and ordination techniques, after the omission of rare species. The classification was based on the Bray Curtis similarity index and group average sorting on $\log (x+1)$ transformed abundance data using the CLUSTAN program on a mainframe computer (Wishart 1978). Detrended correspondence analysis was performed on the $\log (x+1)$ transformed data set using the DECORANA computer program adapted for microcomputers (Hill 1979). 
A computer program by Moore (1983) was used to calculate several species diversity indices, including the Shannon-Wiener information function $\left(H^{\prime}\right)$ and Pielou evenness $\left(J^{\prime}\right)$ (both using $\log _{2}$ ), Simpson's index $(D)$ and the number of species at the 50 individual level using Hurlbert's (1971) rarefaction method (S). MannWhitney $U$-tests were used to test for differences in species diversity indices. $K$-dominance curves were plotted for combined replicates of each treatment on the 3 sampling dates, using the method of Lambshead et al. (1983), and the difference assessed using the procedures of Clarke (1990).

\section{RESULTS}

Altogether 170 nematode species belonging to 106 genera and 31 families were recorded during the course of the study. Of the 87 species retrieved from the background samples, 17 were found in densities reaching more than $1 \%$ of the total nematode number. The 5 most abundant species comprised about $60 \%$ of the total nematode population. Molgolaimus sp. 1 dominated in the samples followed by Terschellingia longicaudata De Mann, Metalinhomoeus sp. 2, Dorylaimopsis punctata Ditlevsen and Setosabatieria hilarula (De Mann). In addition, 141 harpacticoid copepod species belonging to 55 genera and 13 families were found. Of the 67 species found in the background area, 22 were in abundances exceeding $1 \%$ of the total copepod density. The 5 most abundant species comprised about $45 \%$ of the harpacticoid population. These were Haloschizopera sp. a, Cletodes longicaudatus (Boeck), Heteropsyllus major (Sars), Danielssenia typica Boeck and Stenhelia mastigochaeta Wells

\section{Multivariate analysis}

The ordination of the nematode species abundance data (Fig. 1) reveals a high degree of dissimilarity between samples. The ordination does not detect treatment effects as replicate cages do not cluster. There is only a slight recolonization pattern as some of the $1 \mathrm{mo}$ cages are set apart from the rest of the cages (Fig. 1). Though the nematodes were slow to colonize the cages (Olafsson \& Moore 1990) it appears that they reached the background composition after 3 mo.

The ordination of the harpacticoid species data indicates that there was a strong successional trend but a poor or non-existent seasonal trend (Fig. 2). All the BC samples are in the top left corner and there is no clear pattern amongst them. By contrast there is a clear pattern between months for all the treatments (Fig. 2). The $1 \mathrm{~mm}$ cages are after 3 mo spatially close on the

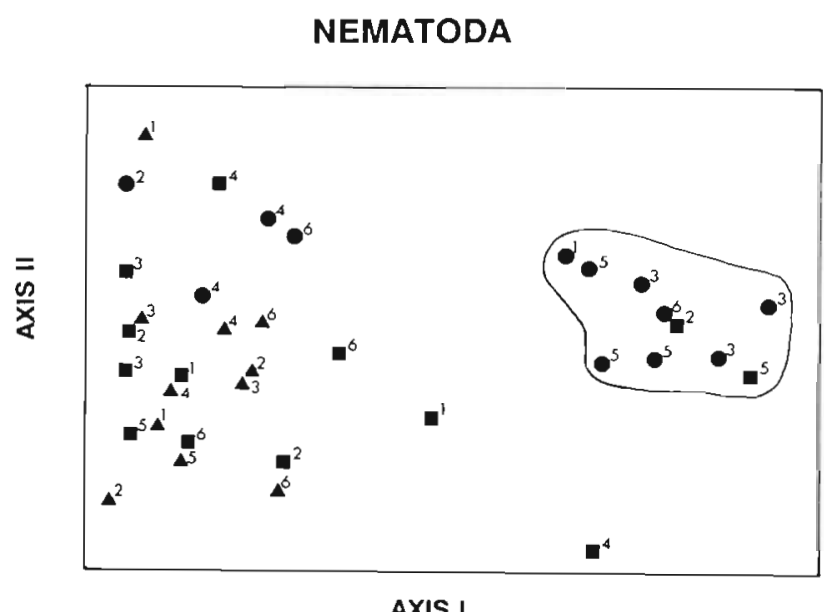

Fig. 1 Two-dimensional configuration (detrended correspondence analysis) of time serjes samples of nematode species

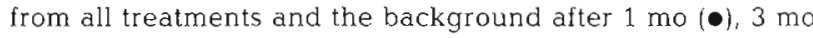
(-) and $8 \mathrm{mo}(\mathbf{\Delta})(1$ = background control, $2=$ open control cages, $3=10 \mathrm{~mm}$ cages, $4=10 \mathrm{~mm}$ control cages, $5=1 \mathrm{~mm}$ cages, $6=1 \mathrm{~mm}$ control cages). Eigenvalues for the first and second axis: $0.202,0.079$ respectively

ordination plot and it was found that the density of harpacticoids was significantly higher than in the rest of the cages (Ólafsson \& Moore 1990). The average number of the most abundant species, Longipedia helgolandica Klie, was almost the same for the $1 \mathrm{~mm}$ cages and the rest of the cages. There were mainly 3 species that accounted for the higher numbers inside the $1 \mathrm{~mm}$ cages. Both Tachidella minuta Sars and Normanella minuta (Boeck) were on average in con-

\section{COPEPODA}

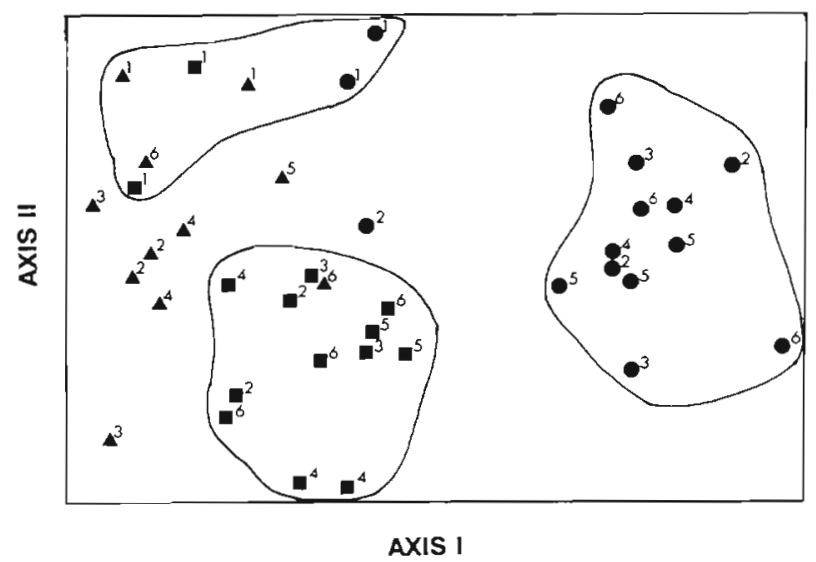

Fig. 2. Two-dimensional configuration (detrended correspondence analysis) of time series samples of harpacticoid species from all treatments and the background after 1 mo ( $), 3$ mo (-) and $8 \mathrm{mo}(\mathbf{A})(1=$ background control, $2=$ open control cages, $3=10 \mathrm{~mm}$ cages, $4=10 \mathrm{~mm}$ control cages, $5=1 \mathrm{~mm}$ cages, $6=1 \mathrm{~mm}$ control cages). Eigenvalues for the first and second axis: $0.172,0.129$ respectively 
siderably higher numbers (Mann-Whitney U-test, $\mathrm{p}=$ 0.067) as well as Ameira parvula (Claus) (MannWhitney $U$-test, $\mathrm{p}<0.05$ )

The results from the cluster analyses are not presented here (consult Ólafsson 1989) but both analyses showed very similar patterns and indicated that the time factor or the successional stage was more important than partial or complete exclusion of the macrofauna. They also indicated that the assemblages were generally more different in cages after 1 mo than from subsequent months.

\section{Univariate analysis}

The $k$-dominance plot of the nematodes after 1 mo of colonization (Fig. 3) indicates no differences between treatments as combined sample curves intersect. After 3 mo all diversity values were similar (Table 1 ) and the $k$-dominance curves all more or less crossed. However, after 8 mo the diversity as measured by $k$-dominance was clearly highest in the $1 \mathrm{~mm}$ cage. There was also an indication of higher diversity within $10 \mathrm{~mm}$ cages than in the control cages (Fig. 3) and on average the diversity values were higher in the exclosure cages than in the control cages. Although this was only significant (MannWhitney $U$-test, $\mathrm{p}<0.05$ ) for Pielou's evenness index and Simpson's index, the Shannon-Wiener index was almost significantly different at the $95 \%$ level (Mann-Whitney $U$-test, $p=0.0528$ ). For individual treatments there was however no difference detected between curves for all dates, using the ANOSIM test (Clarke 1990).

The $k$-dominance curves for the samples after 1 mo (Fig. 4) indicate that the harpacticoids from the experimental cages were less diverse than in the background. Although diversity values from the background were on average higher than in the experimental cages, they were not significantly so $(p>0.05)$. Samples from the third month show that diversity was lower in the open control cages compared with the rest of the treatments (Fig. 4). This was significant (MannWhitney $U$-test, $\mathrm{p}<0.05$ ) for both Shannon-Wiener and Simpson indices but not for $J^{\prime}$ (Mann-Whitney $U$-test, $\mathrm{p}=0.055$ ) and $S$ (Mann-Whitney $U$-test, $\mathrm{p}=0.235$ ). Background diversity values were still on average higher after $3 \mathrm{mo}$, but not significantly so (Table 2; Mann-Whitney $U$-test, p $>0.05$ ). Fig. 4 indicates that diversity after 8 mo inside the $1 \mathrm{~mm}$ cage was higher than in the rest of the treatments and very similar to the background. All diversity indices apart from species richness $(S)$ show higher values inside exclosure cages than the control cages (Mann-Whitney $U$-test, $\mathrm{p}<0.05)$. For individual treatments there was however no difference detected between curves for all dates, using the ANOSIM test.
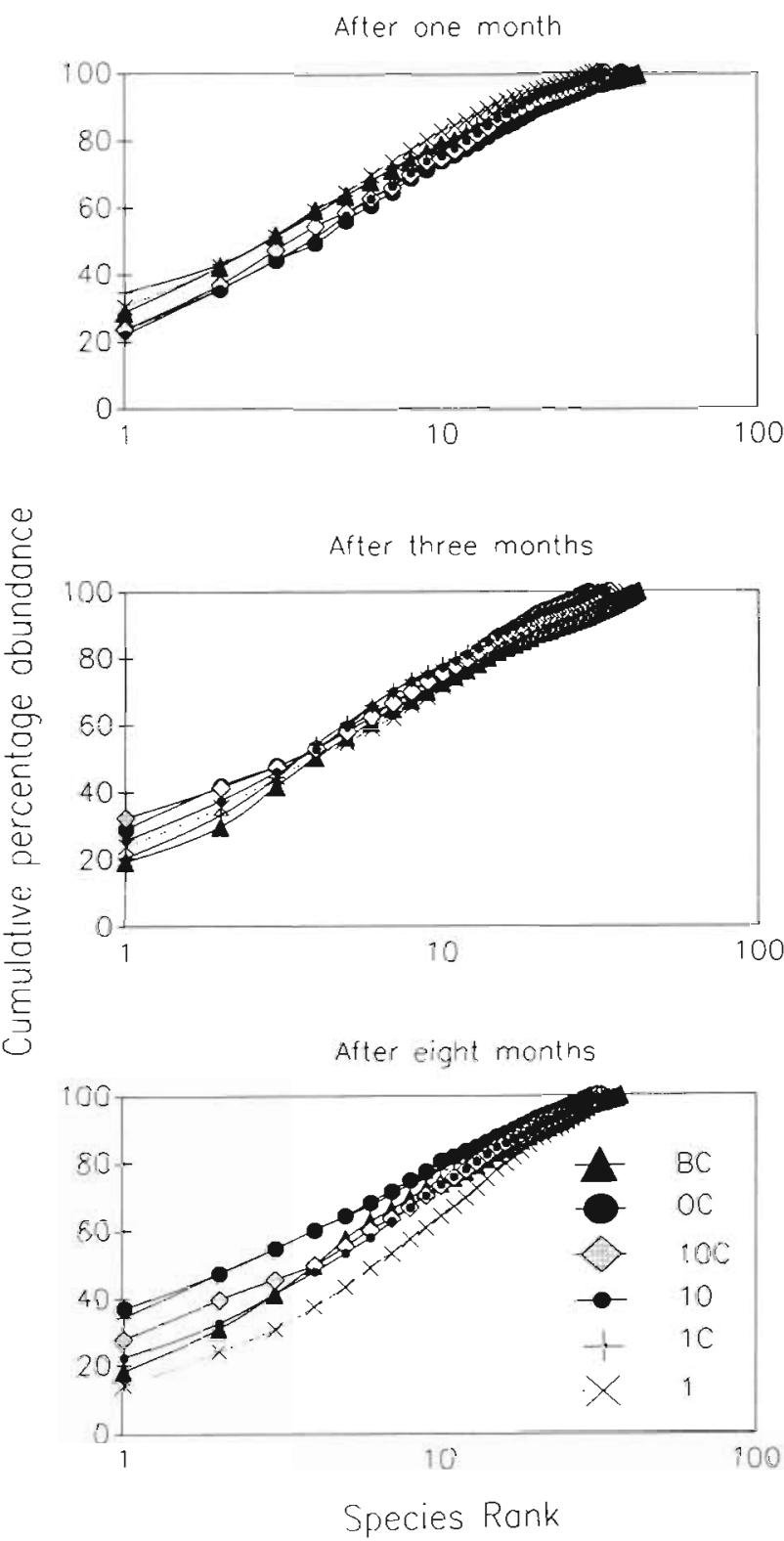

Fig. 3. K-dominance curves derived from combined treatment replicates for all nematode species after 1,3 and 8 mo $(B C=$ background control, $O C=$ open control cages, $10 \mathrm{C}=10 \mathrm{~mm}$ control cages, $10=10 \mathrm{~mm}$ cages, $1 \mathrm{C}=1 \mathrm{~mm}$ control cages, $1=1 \mathrm{~mm}$ cages)

\section{Recolonization}

\section{Nematodes}

The most abundant species in the background, Molgolaimus sp. 1, was after 1 mo dominant in all the cages (Table 1). Other numerically important species in the background, Terschellingia longicaudata, Metalinhomoeus sp. 2 and Setosabatieria hilarula, were also quick to colonize. However, Dorylaimopsis punctata, highly abundant in the background, was in relatively 
Table 1. Average no. per $10 \mathrm{~cm}^{2}$ and percentage abundance of the 15 most abundant nematode species in all treatments and controls $(B C=$ background control, $O C=$ open control cages, $10 \mathrm{C}=10 \mathrm{~mm}$ control cages, $10=10 \mathrm{~mm}$ cages, $1 \mathrm{C}=1 \mathrm{~mm}$ control cages, $1=1 \mathrm{~mm}$ cages). Average species diversity (Shannon-Wiener, Simpson), evenness (Pielou) and richness (Sanders rarefaction at the 50 individual level) is also presented

\begin{tabular}{|c|c|c|c|c|c|c|c|c|c|c|c|c|c|c|c|c|c|c|}
\hline \multirow{3}{*}{$\begin{array}{l}\text { Sampling date: } \\
\text { No. of replicates: } \\
\text { Treatment: }\end{array}$} & \multicolumn{6}{|c|}{ After $1 \mathrm{mo}$} & \multicolumn{6}{|c|}{ After $3 \mathrm{mo}$} & \multicolumn{6}{|c|}{ After 8 mo } \\
\hline & 1 & 2 & 2 & 3 & 2 & 3 & 2 & 2 & 2 & 2 & 3 & 2 & 2 & 2 & 2 & 2 & 2 & 1 \\
\hline & $\mathrm{BC}$ & OC & $10 \mathrm{C}$ & 10 & $1 \mathrm{C}$ & 1 & $\mathrm{BC}$ & OC & $10 \mathrm{C}$ & 10 & $1 \mathrm{C}$ & 1 & $\mathrm{BC}$ & OC & $10 \mathrm{C}$ & 10 & $1 \mathrm{C}$ & 1 \\
\hline & \multicolumn{18}{|c|}{ No. per $10 \mathrm{~cm}^{2}$} \\
\hline Paramesacanthion hirsutum & 22 & 0 & 0 & 5 & 3 & 1 & 11 & 2 & 5 & 8 & 8 & 5 & 19 & 12 & 32 & 38 & 17 & 21 \\
\hline Halalaimus spp. & 44 & 12 & 18 & 14 & 8 & 9 & 13 & 13 & 6 & 3 & 4 & 7 & 16 & 15 & 11 & 51 & 22 & 17 \\
\hline Viscosia sp. 1 & 22 & 16 & 12 & 11 & 2 & 4 & 13 & 17 & 26 & 24 & 17 & 8 & 7 & 32 & 44 & 23 & 32 & 19 \\
\hline Chromadorina sp. 2 & 0 & 10 & 44 & 0 & 9 & 0 & 0 & 37 & 0 & 64 & 11 & 40 & 50 & 2 & 3 & 21 & 10 & 6 \\
\hline Ptycholaimellus sp. 1 & 22 & 20 & 19 & 12 & 8 & 4 & 3 & 23 & 28 & 34 & 7 & 7 & 14 & 34 & 30 & 31 & 11 & 6 \\
\hline Pomponema sp. 1 & 11 & 6 & 0 & 0 & 2 & 0 & 28 & 6 & 0 & 10 & 7 & 1 & 32 & 17 & 28 & 25 & 16 & 10 \\
\hline Richtersia inaequalis & 56 & 31 & 11 & 15 & 23 & 12 & 41 & 30 & 17 & 11 & 9 & 5 & 12 & 0 & 7 & 2 & 9 & 0 \\
\hline Dorylaimopsis punctata & 222 & 15 & 6 & 9 & 15 & 32 & 131 & 19 & 29 & 7 & 3 & 4 & 103 & 32 & 36 & 32 & 37 & 12 \\
\hline Setosabatiriea hilarula & 89 & 31 & 10 & 5 & 15 & 13 & 29 & 22 & 44 & 53 & 46 & 7 & 95 & 97 & 67 & 66 & 60 & 21 \\
\hline Molgolaimus sp.1 & 523 & 124 & 83 & 97 & 108 & 113 & 216 & 191 & 207 & 134 & 52 & 22 & 254 & 341 & 225 & 149 & 268 & 13 \\
\hline Spirina sp.1 & 56 & 7 & 14 & 6 & 5 & 13 & 17 & 10 & 34 & 18 & 12 & 2 & 70 & 34 & 31 & 6 & 12 & 0 \\
\hline Leptolaimus sp. 1 & 44 & 7 & 11 & 21 & 19 & 18 & 55 & 6 & 28 & 9 & 4 & 7 & 32 & 26 & 17 & 12 & 28 & 10 \\
\hline Daptonema sp. 1 & 11 & 20 & 11 & 18 & 5 & 7 & 57 & 57 & 21 & 45 & 53 & 23 & 25 & 64 & 15 & 34 & 93 & 31 \\
\hline Metalinhomoeus sp. 2 & 133 & 34 & 10 & 37 & 26 & 30 & 138 & 11 & 12 & 22 & 21 & 3 & 172 & 42 & 25 & 43 & 23 & 42 \\
\hline \multirow[t]{2}{*}{ Terschellingia longicaudata } & 178 & 34 & 31 & 39 & 35 & 38 & 205 & 16 & 18 & 12 & 6 & 4 & 128 & 16 & 20 & 18 & 5 & 4 \\
\hline & \multicolumn{18}{|c|}{ Percentage abundance } \\
\hline Paramesacanthion hirsutum & 2 & 0 & 0 & 2 & 1 & 0 & 1 & 0 & 1 & 2 & 3 & 4 & 2 & 2 & 5 & 7 & 3 & 10 \\
\hline Halalaimus spp. & 3 & 3 & 6 & 5 & 3 & 3 & 1 & 3 & 1 & 1 & 2 & 5 & 2 & 2 & 2 & 9 & 3 & 8 \\
\hline Viscosia sp. 1 & 2 & 4 & 4 & 4 & 1 & 2 & 1 & 4 & 5 & 5 & 7 & 5 & 1 & 4 & 8 & 4 & 5 & 9 \\
\hline Chromadorina sp. 2 & 0 & 3 & 16 & 0 & 3 & 0 & 0 & 8 & 0 & 14 & 4 & 27 & 5 & 0 & 0 & 4 & 2 & 3 \\
\hline Ptycholaimellus sp. 1 & 2 & 6 & 7 & 4 & 3 & 1 & 0 & 5 & 6 & 8 & 3 & 5 & 1 & 4 & 5 & 6 & 2 & 3 \\
\hline Pomponema sp. 1 & 1 & 2 & 0 & 0 & 1 & 0 & 3 & 1 & 0 & 2 & 3 & 1 & 3 & 2 & 5 & 5 & 2 & 5 \\
\hline Richtersia inaequalis & 4 & 8 & 4 & 5 & 8 & 4 & 4 & 7 & 4 & 2 & 4 & 4 & 1 & 0 & 1 & 0 & 1 & 0 \\
\hline Dorylaimopsis punctata & 15 & 4 & 2 & 3 & 5 & 11 & 14 & 4 & 6 & 1 & 1 & 3 & 10 & 4 & 6 & 6 & 6 & 5 \\
\hline Setosabatiria hilarula & 6 & 8 & 3 & 2 & 5 & 4 & 3 & 5 & 9 & 12 & 18 & 5 & 9 & 13 & 11 & 12 & 9 & 10 \\
\hline Molgolaimus sp. 1 & 37 & 34 & 30 & 33 & 38 & 39 & 23 & 41 & 44 & 30 & 20 & 15 & 25 & 45 & 38 & 27 & 42 & 6 \\
\hline Spirina sp. 1 & 4 & 2 & 5 & 2 & 2 & 4 & 2 & 2 & 7 & 4 & 5 & 1 & 7 & 4 & 5 & 1 & 2 & 0 \\
\hline Leptolaimus sp. 1 & 3 & 2 & 4 & 7 & 7 & 6 & 6 & 1 & 6 & 2 & 2 & 5 & 3 & 3 & 3 & 2 & 4 & 5 \\
\hline Daptonema sp. 1 & 1 & 6 & 4 & 6 & 2 & 2 & 6 & 12 & 4 & 10 & 20 & 16 & 2 & 8 & 3 & 6 & 14 & 15 \\
\hline Metalinhomoeus sp. 2 & 9 & 9 & 3 & 13 & 9 & 10 & 14 & 2 & 2 & 5 & 8 & 2 & 17 & 6 & 4 & 8 & 4 & 20 \\
\hline Terschellingia longicaudata & 12 & 9 & 11 & 14 & 12 & 13 & 21 & 3 & 4 & 3 & 2 & 3 & 12 & 2 & 3 & 3 & 1 & 2 \\
\hline Shannon-Wiener $\left(H^{\prime}\right)$ & 3.87 & 4.15 & 4.01 & 4.08 & 3.75 & 3.70 & 4.29 & 3.90 & 3.90 & 3.92 & 3.96 & 4.23 & 4.21 & 3.66 & 4.05 & 4.16 & 3.74 & 4.53 \\
\hline Simpson $(D)$ & 0.87 & 0.91 & 0.90 & 0.91 & 0.85 & 0.87 & 0.92 & 0.88 & 0.87 & 0.88 & 0.90 & 0.91 & 0.92 & 0.84 & 0.89 & 0.91 & 0.85 & 0.95 \\
\hline Pielou $\left(J^{\prime}\right)$ & 0.76 & 0.82 & 0.80 & 0.81 & 0.75 & 0.77 & 0.81 & 0.80 & 0.79 & 0.78 & 0.82 & 0.81 & 0.82 & 0.74 & 0.81 & 0.83 & 0.75 & 0.89 \\
\hline Richness (S) & 17.0 & 19.0 & 17.8 & 18.7 & 18.1 & 16.5 & 19.5 & 17.0 & 17.6 & 17.3 & 17.1 & 20.5 & 18.8 & 16.6 & 18.7 & 19.2 & 17.1 & 22.0 \\
\hline
\end{tabular}

low numbers in most of the cages after the first month. The recolonization of some species, Chromadorina sp. 2 and Spirinia sp. 1, was sporadic, important in some cages while non-existent in others.

\section{Harpacticoids}

The most successful early colonists were Danielssenia typica, Tachidella minuta and Laophonte longicaudata (Boeck). Of these only D. typica was found in high numbers in the background samples after 1 mo (Table 2). T. minuta remained in relatively high numbers in subsequent months while the other two declined. Longipedia helgolandica was in low numbers in the background areas throughout the experiment (Table 2) but became extremely abundant in all the cages after 3 and 8 mo. It was by far the most abundant species in all the treatments apart from the $1 \mathrm{~mm}$ cages where Tachidella minuta, Normanella minuta and Haloschizopera sp. a were also abundant.

The most abundant species in the background samples, Haloschizopera sp. a and Cletodes longicaudatus were relatively slow colonizers (Table 2). However both species attained background levels, in most of the cages, after 8 mo. 
After one month
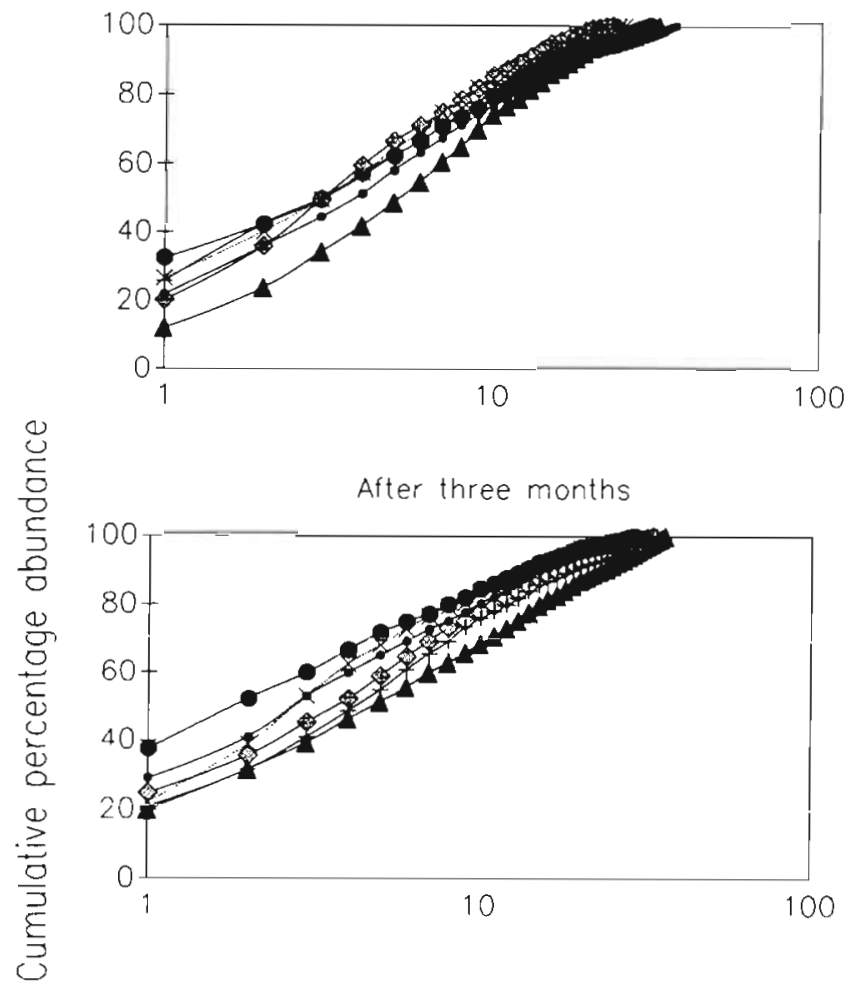

After eight months

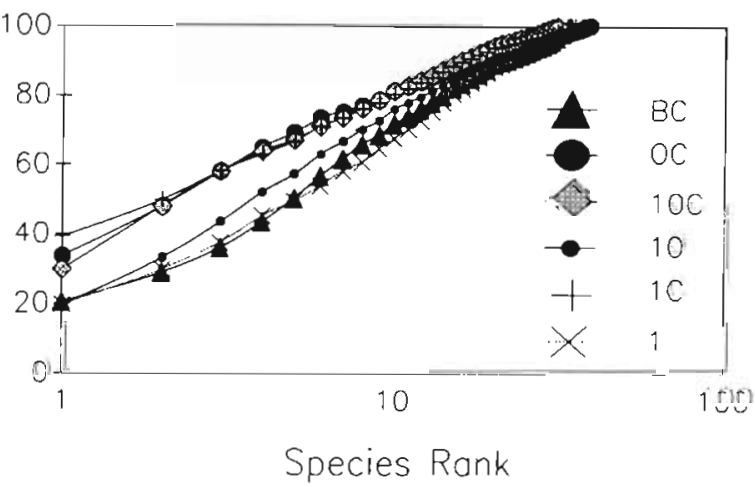

Fig. 4. K-dominance curves derived from combined treatment replicates for all harpacticoid species after 1,3 and $8 \mathrm{mo}$ $(\mathrm{BC}=$ background control, $\mathrm{OC}=$ open control cages, $10 \mathrm{C}=$ $10 \mathrm{~mm}$ control cages, $10=10 \mathrm{~mm}$ cages, $1 \mathrm{C}=1 \mathrm{~mm}$ control cages, $1=1 \mathrm{~mm}$ cages

Both Danielssenia typica and Haloschizopera sp. a colonized the cages mainly as adults (Table 3 ). The proportion of juveniles, inside the cages, for Cletodes longicaudatus and Normanella minuta was high throughout the study. The initial colonization of Longipedia helgolandica and Tachidella minuta was dominated by the juvenile stages (Table 3). In a few cages after 1 and 3 mo Laophonte longicaudata and Pseudobradya similis (T. \& A. Scott) were in high numbers and there they occurred almost solely as copepodites.

\section{DISCUSSION}

\section{Recolonization}

Though the densities of the major taxa were not back to ambient levels after 1 mo of colonization. high diversity assemblages comparable to the background were established in all the cages. Considerable variation in species composition was found in these cages for both nematodes and harpacticoids, and no indication that exclusion of macroepifauna was influencing the early colonizing individuals.

\section{Nematodes}

The colonization of the nematode species in this experiment, and probably in many other subtidal sediments, seems to be governed by 3 major factors. Firstly, the availability of background populations: it is clear that dominant species in the background became most abundant inside the cages. Secondly, on the vertical distribution of recruits: deeper-dwelling nematodes seem to take longer to colonize than surface dwellers. For example, Dorylaimopsis punctata, highly abundant in the background samples, was in relatively low numbers in most of the cages after the first month. This species has been found to be deepdwelling in subtidal sediments on the west coast of Scotland (Bett pers. comm.). Thirdly, by chance: as the background samples show considerable variability, the exact position of a cage is likely to contribute to great variation within a treatment. The variability of nematode composition on a small scale can be very high in soft sediments (Hodda 1990, Ólafsson 1992). Furthermore macrobiological activity on the sediment surface near the cages is likely to affect the initial colonization differently between cages, as such disturbance can happen anywhere around the cages and without predictability. Such disturbance has been shown to enhance nematode drift (Palmer 1988), which is probably an important factor contributing to early colonization over short distances subtidally.

In only one study has the recolonization of nematode species in azoic sediment been investigated for subtidal areas. Alongi et al. (1983) showed that the dominant nematode species in the background colonized azoic trays swiftly and was ranked first in all the experimental trays. They also demonstrated that some relatively deep-dwelling species, abundant in the background, were slow to colonize, which seems to be in accordance with the current study. 
Table 2. Average no. per $10 \mathrm{~cm}^{2}$ and percentage abundance of the 15 most abundant harpactcoid species in all treatments and controls $(\mathrm{BC}=$ background control, $\mathrm{OC}=$ open control cages, $10 \mathrm{C}=10 \mathrm{~mm}$ control cages, $10=10 \mathrm{~mm}$ cages, $1 \mathrm{C}=1 \mathrm{~mm}$ control cages, $1=1 \mathrm{~mm}$ cages). Average species diversity (Shannon-Wiener, Simpson), evenness (Pielou) and richness (Sanders rarefaction at the 50 individual level) is also presented

\begin{tabular}{|c|c|c|c|c|c|c|c|c|c|c|c|c|c|c|c|c|c|c|}
\hline \multirow{3}{*}{$\begin{array}{l}\text { Sampling date: } \\
\text { No of replicates: } \\
\text { Treatment: }\end{array}$} & \multicolumn{6}{|c|}{ After 1 mo } & \multicolumn{6}{|c|}{ After 3 mo } & \multicolumn{6}{|c|}{ After $8 \mathrm{mo}$} \\
\hline & 2 & 3 & 2 & 3 & 2 & 3 & 2 & 2 & 3 & 2 & 3 & 2 & 2 & 2 & 2 & 2 & 2 & 1 \\
\hline & $\mathrm{BC}$ & $O C$ & $10 \mathrm{C}$ & 10 & $1 \mathrm{C}$ & 1 & $\mathrm{BC}$ & OC & $10 \mathrm{C}$ & 10 & $1 C$ & 1 & $\mathrm{BC}$ & $\mathrm{OC}$ & $10 \mathrm{C}$ & 10 & $1 \mathrm{C}$ & 1 \\
\hline & \multicolumn{18}{|c|}{ No. per $10 \mathrm{~cm}^{2}$} \\
\hline Longipedia helgolandica & 2 & 4 & 0 & 1 & 0 & 2 & 2 & 99 & 55 & 77 & 51 & 78 & 2 & 38 & 75 & 43 & 75 & 18 \\
\hline L. scotti & 2 & 2 & 0 & 10 & 2 & 3 & 2 & 7 & 14 & 6 & 13 & 3 & 1 & 1 & 4 & 6 & 8 & 3 \\
\hline Danielssenia typica & 14 & 23 & 23 & 20 & 7 & 17 & 12 & 3 & 1 & 3 & 3 & 6 & 4 & 1 & 5 & 9 & 4 & 6 \\
\hline Tachidella minuta & 1 & 3 & 16 & 6 & 9 & 5 & 3 & 24 & 16 & 24 & 20 & 87 & 2 & 16 & 46 & 35 & 14 & 12 \\
\hline Stenhelia reflexa & 1 & 3 & 1 & 3 & 2 & 3 & 1 & 1 & 5 & 4 & 3 & 4 & 1 & 8 & 15 & 6 & 7 & 3 \\
\hline S. mastigochaeta & 9 & 1 & 2 & 2 & 11 & 0 & 6 & 1 & 2 & 3 & 3 & 5 & 6 & 1 & 2 & 3 & 0 & 1 \\
\hline Haloschizoperasp. a & 17 & 5 & 6 & 6 & 2 & 2 & 36 & 7 & 16 & 8 & 17 & 14 & 23 & 9 & 22 & 25 & 20 & 29 \\
\hline H. pygmea & 0 & 0 & 0 & 0 & 0 & 0 & 2 & 9 & 2 & 3 & 10 & 9 & 1 & 1 & 6 & 9 & 2 & 1 \\
\hline Ameira parvula & 0 & 3 & 3 & 5 & 1 & 7 & 0 & 4 & 7 & 18 & 9 & 46 & 0 & 0 & 0 & 1 & 1 & 0 \\
\hline Proameira echinipes & 8 & 2 & 1 & 2 & $\hat{1}$ & 1 & 6 & 0 & 1 & 0 & 1 & 3 & 4 & 2 & 3 & 1 & 2 & 11 \\
\hline Cletodes longicaudatus & 17 & 13 & 4 & 4 & 2 & 3 & 26 & 15 & 16 & 23 & 11 & 7 & 7 & 6 & 8 & 2 & 6 & 5 \\
\hline Heteropsyllus major & 15 & 2 & 3 & 2 & 2 & 1 & 4 & 3 & 2 & 5 & 5 & 1 & 8 & 1 & 6 & 8 & 4 & 2 \\
\hline Laophonte longicaudata & 6 & 2 & 13 & 14 & 5 & 10 & 1 & 12 & 4 & 6 & 5 & 22 & 1 & 0 & 0 & 0 & 1 & 0 \\
\hline Normanella mucronata & 3 & 1 & 1 & 2 & 1 & 2 & 5 & 4 & 3 & 3 & 2 & 5 & 5 & 3 & 6 & 7 & 5 & 7 \\
\hline \multirow[t]{2}{*}{ N. minuta } & 5 & 3 & 0 & 1 & 1 & 1 & 4 & 36 & 12 & 31 & 13 & 78 & 7 & 4 & 8 & 19 & 3 & 6 \\
\hline & \multicolumn{18}{|c|}{ Percentage abundance } \\
\hline Longipedia helgolandica & 2 & 6 & 0 & 2 & 0 & 4 & 1 & 44 & 35 & 36 & 31 & 21 & 3 & 41 & 36 & 25 & 50 & 17 \\
\hline L. scotti & 2 & 3 & 0 & 12 & 4 & 5 & 1 & 3 & 9 & 3 & 8 & 1 & 1 & 1 & 2 & 3 & 5 & 3 \\
\hline Danielssenia typica & 14 & 34 & 31 & 26 & 16 & 29 & 11 & 2 & 1 & 2 & 2 & 2 & 5 & 1 & 2 & 5 & 2 & 6 \\
\hline Tachidella minuta & 1 & 4 & 22 & 8 & 20 & 9 & 2 & 11 & 10 & 11 & 12 & 24 & 3 & 17 & 22 & 20 & 9 & 12 \\
\hline Stenhelia reflexa & 1 & 4 & 2 & 4 & 4 & 5 & 1 & 0 & 3 & 2 & 2 & 1 & 1 & 9 & 7 & 4 & 5 & 3 \\
\hline S. mastigochaeta & 9 & 1 & 2 & 2 & 26 & 0 & 6 & 1 & 1 & 2 & 2 & 1 & 9 & 1 & 1 & 2 & 0 & 1 \\
\hline Haloschizopera sp. a & 17 & 8 & 8 & 8 & 4 & 3 & 33 & 3 & 10 & 4 & 10 & 4 & 32 & 10 & 11 & 14 & 13 & 28 \\
\hline H. pygmea & 0 & 0 & 0 & 0 & 0 & 0 & 2 & 4 & 2 & 2 & 6 & 3 & 2 & 1 & 3 & 5 & 1 & 1 \\
\hline Ameira parvula & 0 & 5 & 4 & 6 & 1 & 12 & 0 & 2 & 4 & 8 & 5 & 13 & 0 & 0 & 0 & 0 & 1 & 0 \\
\hline Proameira echinipes & 9 & 3 & 1 & 2 & 2 & 1 & 5 & 0 & 0 & 0 & 0 & 1 & 5 & 2 & 1 & 1 & 1 & 10 \\
\hline Cletodes longicaudatus & 17 & 19 & 6 & 5 & 5 & 6 & 24 & 6 & 10 & 11 & 6 & 2 & 9 & 7 & 4 & 1 & 4 & 5 \\
\hline Heteropsyllus major & 15 & 3 & 3 & 2 & 4 & 1 & 4 & 1 & 1 & 2 & 3 & 0 & 11 & 1 & 3 & 5 & 3 & 2 \\
\hline Laophonte longicaudata & 6 & 4 & 18 & 18 & 11 & 18 & 1 & 5 & 3 & 3 & 3 & 6 & 2 & 0 & 0 & 0 & 0 & 0 \\
\hline Normanella mucronata & 3 & 1 & 1 & 2 & 2 & 3 & 4 & 2 & 2 & 2 & 1 & 1 & 7 & 4 & 3 & 4 & 3 & 7 \\
\hline N. minuta & 5 & 4 & 0 & 2 & 1 & 2 & 4 & 16 & 8 & 14 & 8 & 21 & 9 & 4 & 4 & 11 & 2 & 6 \\
\hline Shannon-Wiener $\left(H^{\prime}\right)$ & 4.27 & 3.74 & 3.66 & 4.05 & 3.66 & 3.66 & 4.39 & 3.39 & 3.98 & 3.78 & 4.16 & 3.74 & 4.29 & 3.65 & 3.66 & 4.15 & 3.55 & 4.43 \\
\hline Simpson $(D)$ & 0.94 & 0.87 & 0.90 & 0.91 & 0.89 & 0.89 & 0.93 & 0.82 & 0.90 & 0.88 & 0.91 & 0.89 & 0.93 & 0.85 & 0.86 & 0.92 & 0.82 & 0.93 \\
\hline Pielou $\left(J^{\prime}\right)$ & 0.88 & 0.81 & 0.83 & 0.82 & 0.85 & 0.83 & 0.84 & 0.72 & 0.81 & 0.78 & 0.82 & 0.78 & 0.86 & 0.72 & 0.74 & 0.81 & 0.71 & 0.85 \\
\hline Richness $(S)$ & 19.3 & 18.8 & 14.4 & 19.5 & 18.5 & 17.5 & 20.2 & 15.9 & 17.7 & 17.4 & 19.4 & 15.2 & 20.9 & 20.9 & 16.7 & 19.6 & 17.5 & 21.9 \\
\hline
\end{tabular}

Table 3. Percentage of total numbers of copopodites found in the background and in the experimental cages for the 5 most abundant harpacticoid species and the total number of harpacticoids $(H . \mathrm{sp} . \mathrm{a}=$ Haloschizopera $\mathrm{sp}$. a; C. lon $=\mathrm{Cletodes}$ longicaudatus; $L$. hel = Longipedia helgolandica; D. typ = Danielssenia typica; $T$. min = Tachidella minuta; N. min = Normanella minuta

\begin{tabular}{|clrrrrrrr|}
\hline Month & Treatment & H.sp.a & C.lon & L.hel & D.typ & T.min & N.min & Total \\
\hline 1 & Background & 18 & 54 & 80 & 0 & 0 & 89 & 30 \\
1 & Cages & 18 & 41 & 62 & 17 & 72 & 88 & 52 \\
3 & Background & 6 & 45 & 50 & 0 & 0 & 27 & 41 \\
3 & Cages & 11 & 54 & 58 & 8 & 12 & 75 & 47 \\
8 & Background & 4 & 40 & 0 & 0 & 19 & 77 & 21 \\
8 & Cages & 3 & 54 & 0 & 0 & 7 & 59 & 14 \\
\hline
\end{tabular}




\section{Harpacticoids}

The harpacticoid species Danielssenia typica was the most abundant species in 8 of 14 cages after 1 mo, displaying various degrees of dominance and being more abundant than in the background. Studies on the initial recolonization phases of macrofauna in soft bottom habitats have shown that some species at relatively low densities in ambient or control sediments can become abundant in the open habitat (Grassle \& Sanders 1973, McCall 1977, Bonsdorff 1980, VanBlaricom 1982). D. typica is commonly found in subtidal muddy sediments (Bossanyi \& Bull 1971, Moore 1979, Gee et al. 1985) and was the dominant species colonizing floating platforms containing mud (Scheibel 1974). The form of the body of $D$. typica indicates an epibenthic mode of living which would be advantageous for an early colonist, as entry to the water column is easier than for species living deeper in the sediment.

The low abundance inside the experimental cages of the dominant harpacticoids in the background, Cletodes longicaudatus and Haloschizopera sp. a, indicates a low grade of dispersal. C. longicaudatus is a typical burrowing species and has, in common with many other cletodids, a thick and heavy cuticle making it difficult for it to become suspended into the water column where hydrodynamic forces are modest. On the other hand Haloschizopera sp. a is a small and light harpacticoid but with inbenthic shape of the body (sensu Marcotte 1983) and the slow colonization may reflect that it is a relatively deep-dwelling animal. Inappropriate sediment conditions inside the cages may also have contributed to slow colonization.

Longipedia spp. are regularly found in the water column (Wells 1980, Onbé 1984, Onbé \& Kimoto 1985, Palmer 1988) as well as in sediments (Moore 1979, Thielemans \& Heip 1984, Hardy \& Barnett 1986) and can be considered as semi-pelagic (Coull \& Vernberg $1970,1975)$. Although usually recorded only in small quantities (Wells 1980) they have been found abundantly (Onbé \& Kimoto 1985). High frequency of $L$ helgolandica inside the guts of some epibenthic predators (Alheit \& Scheibel 1982, authors' pers. obs.) is further support for epibenthic existence. Olafsson et al. (1990) found Longipedia spp. to be rapid colonizers of faecal mounds at the same site. While L. helgolandica was rarely found in the background samples throughout the study, it was an important colonizer in the experimental cages. It is clear that this species colonizes the open habitat mainly through juvenile stages as copepodites dominated in the samples, both from the first and the third month. There are at least 2 possible explanations of this pattern. Firstly, one might suspect that the breeding season or the availability of juveniles is restricted to the months following the first sampling date in July. However, the presence of many Longipedia copepodites in one of the cages after 1 mo throws some doubt on the explanation that the reproductive activity alone accounts for high abundance after 3 mo. Although nothing is known about the breeding season of $L$. helgolandica, the closely related species L. minor showed a prolonged breeding season that lasted for over 7 mo from March to November where copepodites represented a high percentage $(41.3 \%)$ of the total mean annual population in the Southern Bight of the North Sea (Huys et al. 1986).

Another possible explanation is that naupliar larvae, hatching from eggs, settle down directly on to the sediment both inside and outside the cages and the copepodites are not found until after 3 mo as naupliar development may take longer than 1 mo. The low abundance in the background may then be explained by decreased survival rate of the naupliar stages due to biological interactions (predation, competition) or other unfavourable conditions. A number of studies on macrofaunal larval settlement have shown that the survival rate of the juvenile stages is highly dependent on resident species in soft bottom communities (Williams 1980, Wilson 1980, 1981, Oliver et al. 1982, Watzin 1983, 1986), which can be preying directly on the larvae or can disturb the sediment causing indirect mortality. One can assume that inside all the cages during the first 2 mo macrofaunal density was very low, as after 3 mo both macrofaunal density and species richness was substantially lower in all the cages than in the background (Olafsson \& Moore 1990). Furthermore, the most abundant macrofauna species in the background, Melinna palmata, Apistobranchus tullbergi and Paraonidae spp., were, for example, not found in the experimental cages after 3 mo.

However, it has been shown that copepods can select areas to settle (Ravenel \& Thistle 1981, Decho \& Castenholz 1986) and one cannot rule out that sediment modification inside the cages provided in some way resources that may have attracted Longipedia helgolandica.

It is clear that the juvenile stages played an important role in the recolonization. Copepodites have been reported to colonize azoic sediments more rapidly than adults (Kern \& Bell 1984, Kern 1990). This may be due to ontogenetic differences in the vertical distribution of the copepods. Huys et al. (1986) found for example, that copepodites of Pseudobradya beduina Monard were concentrated in the overlaying water while the adults where in the sediment.

\section{Macrofaunal exclusion}

If the macroepifauna is controlling the meiofaunal populations at this site either by direct predation or 
by disturbance, one would expect increased density inside the exclosure cages. Furthermore, one would expect that subordinate species would become abundant if released from competition. The meiofauna was, after $1 \mathrm{mo}$, still in its initial phase of recolonization, where many factors may have contributed to variability occurring inside the cages. However inside the $1 \mathrm{~mm}$ cages after 3 mo the copepods responded by density enhancement (Ólafsson \& Moore 1990). The exclusion did not, however, result in a simpler community as one would expect if suppression of dominant competitive relationships by macroepifauna occurred

In soft-bottom habitats there are many levels of species interaction which may explain why these communities do not respond to exclusion of potential predators in the same manner as relatively simpler rocky shore communities. Many of the infauna are predators themselves and can regulate the abundances of other infaunal species (Reise 1979, Commito 1982, Oliver et al. 1982, Ambrose 1984a). Furthermore there are predators within the meiofaunal communities which consume either other meiofauna or juveniles of macrofaunal animals (Watzin 1985). When released from epibenthic predation predatory infaunal animals become more abundant and may consequently act as intermediate predators (Ambrose 1984a) and hence restrict competition among prey species.

In this experiment there was no sign of increased density of predatory infauna. However Ophryotrocha spp., detritus-feeding polychaetes, became very abundant inside the exclosures. These species are most likely controlled mainly by small epibenthic predators as they were most abundant inside the $1 \mathrm{~mm}$ cage, although control by bigger predators also seem to occur, as numbers were also higher inside the $10 \mathrm{~mm}$ cages. A recorded reduction in overall copepod density after 8 mo (Ólafsson \& Moore 1990) may be explained by increasing competition between the copepods and these polychaetes over food resources. However no data are available on the quality and quantity of food resources inside the cages so other explanations may be valid.

To test ecological theories that predict that under a low intensity of disturbance diversity is low due to competitive exclusion, while intermediate disturbance yields high diversity by preventing competition, using epibenthic disturbers (predators) in soft-bottom communities remains difficult. This is due to highly complicated species interactions in this habitat where multitrophic mechanisms may be of vital importance. Theoretical concepts of predation and disturbance processes in soft-bottom habitats are still mainly tentative as experimental data are scarce.
Acknowledgements. We are grateful to Brian Bett, Dave Mills, Bob Collington, Gareth Davies, Chris Smith, Alan Hughes and Keith Watson for diving assistance. Thanks are also due to Michel Clement for checking the identity of the Ectinosomatidae. Bertil Widbom commented on an earlier draft of the manuscript. The first author acknowledges the receipt of grants from the Foreign and Commonwealth Office and the University of Iceland. Special appreciation goes to Ragnar Elmgren and Hallvardur Einvardsson for their continuous support.

\section{LITERATURE CITED}

Alheit, J., Scheibel, W. (1982). Benthic harpacticoids as a food source for fish. Mar. Biol. 70: 141-147

Alongi, D. M., Boesch, D. F., Diaz, R. J. (1983) Colonization of meiobenthos in oil-contaminated subtidal sands in the lower Chesapeake Bay. Mar. Biol. 72: 325-335

Ambrose, W. G. (1984a). Role of predatory infauna in structuring marine soft-bottom communities. Mar. Ecol. Prog Ser. 17: 109-115

Ambrose, W. G. (1984b). Influence of residents on the development of a marine soft-bottom community. J. mar. Res 42: $633-654$

Ambrose, W. G. (1984c). Influences of predatory polychaetes and epibenthic predators on the structure of a soft-bottom community in a Maine estuary. J. exp. mar. Biol Ecol. 81 $115-145$

Ambrose, W. G. (1986). Importance of predatory infauna in marine soft-bottom communities: reply to Wilson. Mar Ecol. Prog. Ser. 32: 41-55

Bonsdorff, E. (1980). Macrozoobenthos recolonization of a dredged Brackish water bay in SW Finland. Ophelia 1 $145-155$

Bossanyi, J., Bull, H. O. (1971). The marine fauna of Cullercoats district. 5. Arthropoda 3C: Crustacea, Copepoda Rep. Dove Mar. Lab. Ser. 3 No. 17

Clarke, K. R. (1990). Comparisons of dominance curves J. exp. mar. Biol. Ecol. 138: 143-157

Commito, J. A. (1982). Importance of predation by infaunal polychaetes in controlling the structure of a soft-bottom community in Maine, USA. Mar. Biol. 68: 77-81

Commito, J. A., Ambrose, W G. Jr (1985a). Multiple trophic levels in soft-bottom communities. Mar. Ecol. Prog. Ser. 26: $289-293$

Commito, J. A., Ambrose, W. G. (1985b). Predatory infauna and tropic complexity in soft-bottom communities. In Gibbs, P. E. (ed.) Proc, 19th European Marine Biology Symposium. Cambridge University Press, Cambridge, $\mathrm{p}$ 323-333

Commito, J. A., Shrader, P. B. (1985). Benthic community response to experimental additions of the polychaete Nereis virens. Mar. Biol. 86: 101-107

Connell, J. H. (1970). A predator-prey system in the marine intertidal region. 1. Balanus glandula and several predatory species of Thais. Ecol. Monogr. 40:49-76

Connell, J. H. (1978). Diversity in tropical rain forests and coral reefs. Science 199: 1301-1310

Coull, B. C., Vernberg, W. B. (1970). Harpacticoid copepod respiration: Enhydrosoma proprinquum and Longipedia helgolandica. Mar. Biol. 5: 341-344

Coull, B. C., Verneberg, W. B. (1975). Reproductive periodicity of meiobenthic copepods: seasonal or continuous? Mar. Biol. 32: 289-293

Creed, E. L., Coull, B. C. (1984). Sand dollar, Mellita quin- 
quiesperfortata (Leske), and sea pansy, Renilla reniformis (Cuvier) effects on meiofaunal abundance. J. exp. mar. Biol Ecol. 84: 225-234

Dayton, P. K. (1971). Competition disturbance and community organization. The provision and subsequent utilization of space in a rocky intertidal community. Ecol. Monogr. 41: 351-389

Decho, A. W. Castenholz, R. W. (1986). Spatial patterns and feeding of meiobenthic harpacticoid copepods in relation to resident microbial flora. Hydrobiologia 167/168: 497-504

Gee, J. M., Warwick, R. M., Davey, J. I., George, C. L. (1985). Field experiments on the role of epibenthic predators in determining prey densities in an estuarine mudflat. Estuar. coast. Shelf. Sci. 21: 429-488

Grassle, J. F., Sanders, H. L. (1973). Life histories and the role of distubance. Deep Sea Res. 20: 643-659

Hardy, B. L. S., Barnett, P. R. O. (1986). The biology of harpacticoid copepods in the meiofauna of shallow subtidal sands. Proc. R. Soc. Edinb. 90B: 303-316

Hicks, G. F. R. (1984). Spatio-temporal dynamics of a meiobenthic copepod and the impact of predation-disturbance. J. exp. mar. Biol. Ecol, 81: 47-72

Hill, M. O. (1979). DECORANA - a FORTRAN program for detrended correspondence analysis and reciprocal averaging. Cornell University, Ithaca, New York

Hodda, M. (1990). Variation in estuarine littoral nematode populations over three spatial scales. Estuar, coast. Shelf Sci. 30: $325-340$

Holland, A. F., Mountford, N. K., Hiegel, M. H., Kaumeyer, K. R., Mihursky, J. A. (1980). Influence of predation on infaunal abundance in upper Chesapeake Bay, USA. Mar. Biol. 57: 221-235

Hurlbert, S. M. (1971). The non-concept of species diversity: a critique and alternative parameters. Ecology 52: 577-586

Huston, M. (1979). A general hypothesis of species diversity. Am. Nat. 113: 81-110

Huys, R., Herman, R. L., Heip, C. (1986). A seasonal fluctuations in vertical distribution and breeding activity of a subtidal harpacticoid community in the southern Bight, North Sea. Neth. J. Sea Res. 20(4): 375-383

Kent, A. C., Day, R. W. (1983). Population dynamics of an infaunal polychaete: the effect of predators and an adultrecruit interaction. J. exp. mar. Biol Ecol. 73: 185-203

Kern, J. C. (1990). Active and passive aspects of meiobenthic copepod dispersal at two sites near Mustang Island, Texas. Mar. Ecol. Prog. Ser. 60: 211-223

Kern, J. C., Bell, S. S. (1984). Short-term temporal variation in population structure of two harpacticoid copepods Zausodes arenicolus and Paradactylopoida brevicornis. Mar. Biol. 84: 53-63

Lambshead, P. J. D., Platt, H. M., Shaw, K. M. (1983). The detection of differences among assemblages of marine benthic species based on an assessment of dominance and diversity. J nat. Hist. 17: 859-874

Marcotte, B. M. (1983). The imperatives of copepod diversity preception, cognition, competition and predation. In Schram, F. R. (ed.) Crustacean phylogeny. Balkema, Rotterdam, p. $44-72$

McCall, P. L. (1977). Community patterns and adaptive strategies of the infaunal benthos of Long Island Sound. J. mar. Res 35: $221-265$

Menge, B. A.. Sutherland, J. P. (1976). Species diversity gradients: synthesis of the role of predation, competition and temporal heterogeneity. A.m. Nat. 110: 351-369

Moore, C. G. (1979). The identification of faunal gradients and associations of meiobenthic copepods by multivariate analyses. J. mar. biol. A.ss. U.K. 59:725-736
Moore, C. G. (1983). A. BASIC program for the investigation of species diversity. Wat. Pollut. Control 82: 102-106

Naqvi, S. M. Z. (1968). Effects of predation on infaunal invertebrates of Alligator Harbor, Florida. Gulf Res. Rep. 2: $313-321$

Ólafsson, E. (1989). The control of meiobenthic community structure by macrofauna in a subtidal muddy habitat. Ph.D. thesis, Heriot-Watt University, Edinburgh

Olafsson, E. (1992). Small-scale spatial distribution of marine meiobenthos: the effects of decaying macrofauna. Oecologia 90: $37-42$

Olafsson, E., Elmgren, R. (1991). The effects of biological disturbance by benthic amphipods Monoporeia affinis on meiobenthic community structure: a laboratory approach. Mar. Ecol. Prog. Ser. 7: 179-184

Ólafsson, E., Moore, C. G. (1990). Control of meiobenthic abundance by macroepifauna in a subtidal muddy habitat. Mar. Ecol. Prog. Ser. 65: 241-249

Olafsson, E., Moore, C. G., Bett, B. (1990). The impact of Melinna palmata Grube, a tube-building polychaete, on meiofaunal community structure in a soft-bottom subtidal habitat. Estuar. coast. Shelf Sci. 31: 883-893

Oliver, J S., Oakden, J. M., Slattery, P. N. (1982). Phoxocephalid amphipod crustaceans as predators on larvae and juveniles in marine soft-bottom communities. Mar Ecol. Prog. Ser. 7: 179-184

Onbé, T (1984). The developmental stages of Longipedia americana (Copepoda: Harpacticoida) reared in the laboratory. J. Crust. Biol. 4(4): 615-631

Onbé, T., Kimoto, Y (1985). Growth and reproduction of Longipedia sp. (Copepoda: Harpacticoida) in laboratory cultures. Spec. Publ. Mukaishima Mar. Biol. Stn.: 205-212

Paine, R. T. (1966). Food web complexity and species diversity. Am. Nat. 100: 65-75

Palmer, M. A. (1988). Epibenthic predators and marine meiofauna: separating predation, disturbance, and hydrodynamic effects. Ecology 69: 1251-1259

Peterson, C. H. (1979) Predation, competitive exclusion and diversity in the soft benthic communities of estuaries and lagoons. In: Livingston, R. J. (ed.) Ecological processes in coastal and marine systems. Plenum Press, New York, p. 233-264

Platt, H. M., Lambshead, P. J. D. (1985). Neutral model analysis of patterns of marine benthic species diversity. Mar. Ecol. Prog. Ser. 24: 75-81

Platt, H. M. Warwick, R. M. (1983). Free-living marine nematodes. Part I. British Enoplids. In: Kermach, D. M., Barnes, R. S. K. (eds.) Synopses of the British Fauna (New Series) 38. Cambridge University Press, Cambridge, p. $1-307$

Ravenel, W. S., Thistle, D. (1981). The effect of sediment characteristics on the distribution of two subtidal harpacticoid species. J. exp. mar. Biol. Ecol. 50: 289-301

Reidenauer, J A., Thistle, D. (1981). Response of a softbottom harpacticoid community to stingray (Dasyatis sabina) disturbance. Mar. Biol. 65: 261-267

Reise, K. (1977). Predator exclusion experiments in an intertidal mudflat. Helgoländer wiss. Meeresunters. 30: 263-271

Reise, K. (1979). Moderate predation on meiofauna by the macrobenthos of the Wadden Sea. Helgoländer wiss. Meeresunters. 32: 453-465

Reise, K., Ax, P. (1979). A meiofaunal 'thlobios' limited to the anaerobic sulfide system of marine sand does not exist. Mar. Biol. 54: 225-237

Scheibel, W. (1974). Submarine experiments on benthic colonization of sediments in Western Baltic Sea 2. Meiofauna. Mar. Biol. 28: 265-268 
Schubert, A., Reise, K. (1986) Predatory effects of Nephtys hombergii on other polychaetes in tidal flat sediments. Mar. Ecol. Prog. Ser. 34: 117-124

Seinhorst, J W. (1959). A rapid method for the transfer of nematodes from fixative to anhydrous glycerine. Nematologica 4: 67-69

Sherman, K. M., Reidenauer, J. A., Thistle, D., Meeter, D. (1983). Role of natural disturbance in an assemblage of marine free-living nematodes. Mar. Ecol. Prog. Ser. 11: $23-30$

Thielemans, L. K. H., Heip, C. (1984). The response of a harpacticoid copepod community to sediment disturbances in a semi-enclosed lagoon. Hydrobiologia 118: 127-133

Thistle, D. (1980). The response of a harpacticoid copepod community to a small-scale natural disturbance. J. mar. Res. 38: 381-395

VanBlaricom, G. R. (1982). Experimental analysis of structural regulation in a marine sand community exposed to oceanic swell. Ecol. Monogr. 52: 283-305

Virnstein, R. W. (1977). The importance of predation by crabs and fishes on benthic infauna in Chesapeake Bay. Ecology 58: $1199-1217$

Warwick, R. M., Gee, J. M., Berge, J. A., Ambrose, W. (1986). Effects of the feeding activity of the polychaete Streblosoma bairdi (Malmgren) on meiofaunal abundance and community structure. Sarsia. 71. 11-16

Warwick, R. M., Clarke, K. R., Gee, J. M. (1990). The effect of disturbance by soldier crabs Mictyris platycheles H. Milne Edwards on meiobenthic community structure. J. exp. mar. Biol. Ecol. 135: 19-33

This article was submitted to the editor
Watzin, M. C. (1983). The effects of meiofauna on settling macrofauna: meiofauna may structure macrofaunal communities. Oecologia (Berl.) 59: 163-166

Watzin, M. C. (1985). Interactions among temporary and permanent meiofauna: observations on the feeding and behavior of selected taxa. Biol. Bull. 169: 397-416

Watzin, M. C. (1986). Larval settlement into marine softsediment systems: interactions with the meiofauna. J. exp. mar. Biol. Ecol. 98: 65-114

Wells, J. B. J. (1980). A revision of the genus Longipedia Claus (Crustacea: Copepoda: Harpacticoida). Zool. J. Linn. Soc. 70: $103-189$

Williams, J. G. (1980). The influence of adults on the settlement of spat of the clam Tapes japonica. J. mar. Res. 38: $729-741$

Wilson, W. H. Jr (1980). A laboratory investigation of the effect of a terebellid polychaete on the survivorship of neired polychaete larvae. J. exp. mar. Biol. Ecol. 46: 73-80

Wilson, W. H. Jr (1981). Sediment-mediated interactions in a densely populated infaunal assemblege: the effects of the polychaete Abarenicola pacifica. J. mar. Res. 39: 735-748

Wiltse, W. I. (1977). Effects of predation by Polinices duplicatus (Gastropoda: Naticidae) on a sand-flat community. Biol. Bull. 153: 450-451

Wiltse, W. I. (1980). Effects of Polinices duplicatus (Gastropoda: Naticidae) on infaunal community structure at Barnstable Harbor, Massachusetts, U.S.A. Mar. Biol. 56: 301-310

Wishart, D. (1978). Clustan. User manual, cluster analysis package. Program Library Unit, Edinburgh University

Manuscript first received: May 10, 1991

Revised version accepted: May 22, 1992 